\title{
The taxonomic position of Orthoplecta Brady, 1884 (Foraminiferida)
}

\author{
STEFAN A. REVETS' ${ }^{\prime} \&$ JOHN E. WHITTAKER ${ }^{2}$ \\ 1. Koninklijk Belgisch Instituut voor Natuurwetenschappen, Department of Palaeontology, \\ Vautierstraat 29, B-1040 Brussels, Belgium.
}

2. British Museum (Natural History), Department of Palaeontology, Cromwell Road, London SW7 5BD, U.K.

\begin{abstract}
The type species of Orthoplectu, contrary to previous descriptions, possesses an Elongobula-like furrowed apertural face, with a distinct toothplate. Orthoplecta is reclassified in the Buliminacea in the family Orthoplectidae, herein raised to family status. The Orthoplectidae is redefined to include the genera Orthoplecta, Elongobula and Floresina. The occurrence in Orthoplecta of morphological features characteristic of both Floresina and Buliminoides raises questions concerning the evolution of these foraminifera.
\end{abstract}

\section{INTRODUCTION}

Among the many taxa described by Brady (1884) from material collected by the 'Challenger' expedition, Cassidulina (Orthoplecta) clavata is one of the more exotic species. It's remarkable cylindrical form, together with it's puzzling suture pattern set it quite apart from the other cassidulinids (Fig. 1). The aperture, according to Brady $(1884$, p.432) is characterised as 'an oblique loop-like opening on the face of the final segment close to the distal end'.

Subsequent authors did not go beyond reproducing Brady's figures and description (Chapman, 1902; Chapman \& Parr, 1936; Cushman, 1927 et seq.; Galloway, 1933; RauzerChernousova \& Fursenko, 1959), and, like Brady, included the taxon within the Cassidulinidae.

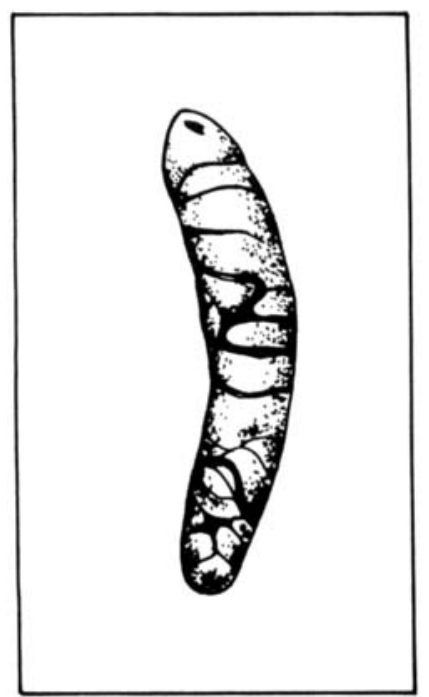

Fig. 1. A reproduction of Brady's (1884) drawing of Cassidulina (Orthoplecta) clavata. Note especially the supposed aperture close to the apex of the test.
Loeblich \& Tappan (1955) studied type material as well as additional specimens in their redescription of Orthoplecta clavata, which drew attention to the irregular chamber arrangement and to the subterminal, ovate aperture, thus endorsing Brady's original description (Fig. 2). Orthoplecta, along with Islandiella, Cassidulinoides and Stichocassidulina, was classified by Loeblich \& Tappan (1964) in the new family Islandiellidae, because it possessed a radial wall structure and a coiling mode neither cassiduline nor biserial in the earlier stages.

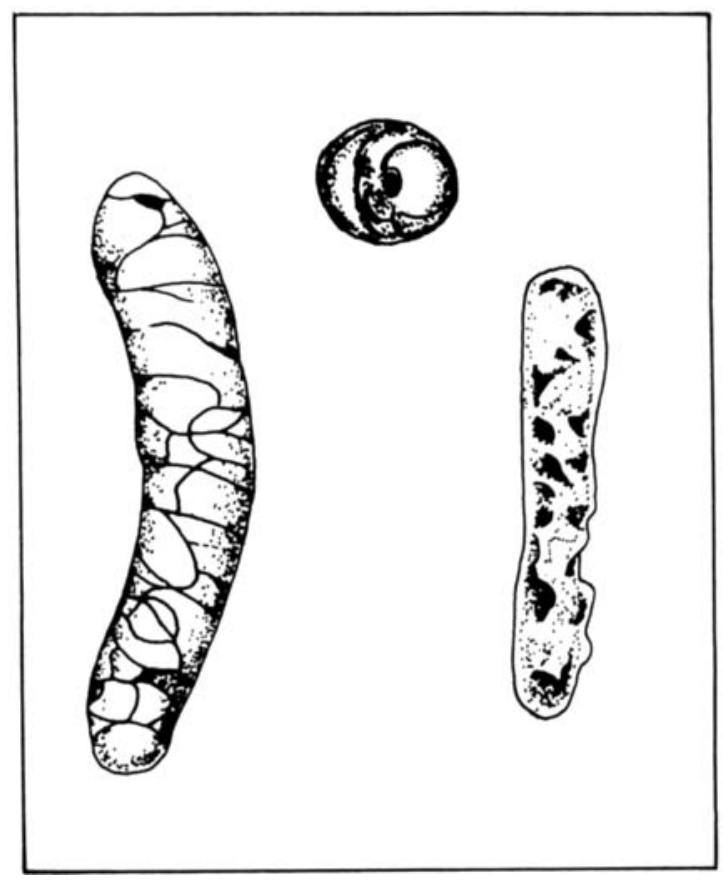

Fig. 2. A reproduction of the drawings of Orthoplecta clavata by Loeblich \& Tappan, 1955. Note that the aperture is drawn as in the original figure by Brady. The dissected specimen on the right-hand side shows the peculiar coiling mode. 
Haynes (1981) placed the Islandiellidae in the Cassidulinacea, with the same member taxa as proposed by Loeblich \& Tappan, including Orthoplecta.

In 1984, Loeblich \& Tappan created for Orthoplecta the new subfamily Orthoplectinae, in the Islandiellidae, Eouvigerinacea, differentiating it from the other islandiellids on account of its elongate, uncoiled test and lack of distinct chambers and septa. The subfamily definition also included the presence of a spiralling internal column, equated with a modification of the toothplate, and an elongate, subterminal aperture just above the base of the final chamber. In their latest classification, the Orthoplectinae remained monotypic, but now as a subfamily of the Cassidulinidae, Cassidulinacea, the Islandiellidae having been synonymised into the Cassidulinidae (Loeblich \& Tappan, 1988).

\section{SYSTEMATICS}

Order Foraminiferida Eichwald, 1839

Suborder Rotaliina Lankester, 1885

Superfamily Buliminacea Jones, 1875

Family Orthoplectidae Loeblich \& Tappan, 1984

1982 Orthoplectinae Loeblich \& Tappan: 33, nomen nudum. 1984 Orthoplectinae Loeblich \& Tappan: 43.

Description. Test free, chambers in high trochospiral coils. multi/pluriserial, up to 9 chambers in whorl; aperture partially hidden by a drawn-out flap, equatorial face furrowed, a massive and simple toothplate running from aperture to foramen; wall calcareous hyaline, perforate.

\section{Genus Orthoplecta Brady, 1884}

1884 Cassidulina (Orthoplecta) Brady: 432.

1927 Orthoplecta Brady; Cushman: 84.

Description. Test free, cylindrical, multilocular, uniserial; asymmetrical chambers arranged in a corkscrew-like fashion; sutures irregular, flush; aperture terminal, furrowed, toothplate present; wall calcareous, perforate, appearing optically radial. Type species. Cassidulina (Orthoplecta) clavata Brady, 1884.

Orthoplecta clavata Brady, 1884

Pl.1, figs 1-8; Text-figs 1-3

1884 Cassidulina (Orthoplecta) clavata Brady: 432, pl.113, fig.9.
1915 Cassidulina (Orthoplecta) clavata Brady; Heron-Allen \&

Earland: 654, pl.50, figs 21, 22.

1927 Orthoplecta clavata Brady: Cushman; 84, p1.18, fig.5.

1955 Orthoplecta clavata Brady; Loeblich \& Tappan: 24, pl.4, figs $1,2$.

1988 Orthoplecta clavata Brady; Loeblich \& Tappan: 508, pl.561, figs 8-10.

Holotype. British Museum (Natural History) [BMNH] No.ZF 2064. Figured by Brady, 1884, pl.113, fig.9, see Text-figs 1, 2, herein.

Type locality. Nares Harbour, Admiralty Islands (north of New Guinea), $17 \mathrm{fms}$, anchor mud, 'Challenger' Station 219A.

Material examined. The holotype. Also BMNH No.ZF 3630, figured by Loeblich \& Tappan, 1955 (refigured in Text-fig.2 and Pl.1, figs 3, 4, 7, 8, herein) and 5 specimens (2 of which, BMNH Nos ZF 4860 and 4861, are figured in Pl.1, figs 1, 2, 5, 6) from Sidebottom 'Type slide' C19, square 19, all from off Raine Island, Torres Strait, 155 fms, 'Challenger' Station 185. Description. Test free, cylindrical, very elongate, may be arcuate, periphery flush, pseudoserial, around 15 chambers in a corkscrew rectilinear series, pseudoseriality around 6; chambers disk-like, much wider than high, as wide as the test diameter, oblique, uneven thickness, flush with the surface; sutures distinct, flush with the surface, oblique, may show 2 nicks where the chamber pinches in, giving an overall irregular appearance; apertural face terminal, circular, slightly inflated, aperture a small central opening, almost entirely covered by a low broad flap, flap apparently resorbed when converted to foramen, surrounded by a few radiating furrows, furrows continue over the edge of the apertural face, toothplate descends from upper end of the aperture, becoming thinner while crossing the lumen, widening at the foraminal aperture, becoming thinner while crossing the lumen, widening at the foraminal attachment site to a semi-circular trough, one edge remains attached to chamber wall; wall hyaline, calcareous, perforate (pores $0.2 \mu \mathrm{m}$ ), smooth; all investigated specimens appear to be megalospheric. Dimensions. Holotype (ZF 2064): length $560 \mu \mathrm{m}$, max. thickness $105 \mu \mathrm{m}$. Figured specimens: ZF 4860 - length $410 \mu \mathrm{m}$, max. thickness $85 \mu \mathrm{m}$; ZF 4861 - length $520 \mu \mathrm{m}$, max. thickness $100 \mu \mathrm{m}$; ZF 3630 - length $430 \mu \mathrm{m}$.

\section{Explanation of Plate 1}

Figs 1-8 Orthoplecta clavata Brady, from 'Challenger' Station 185, Raine Island, Torres Strait. Figs 1, 5, 6, BMNH No.ZF 4860. Fig. 2, BMNH No. ZF 4861. Figs 3, 4, 7, 8, BMNH No. ZF 3630 .

Figs 1, 2. Overall view, showing the cylindrical nature of the test and the smooth walls (scale bar - 100 $\mu \mathrm{m}$ ).

Fig.5. Close-up of the apertural face. The aperture is hidden by a low, broad flap, with grooves radiating away from it (scale bar - 10 $\mu m$ ).

Fig.6. Close-up of the test wall. Note the smooth nature of the wall and the minute pores (scale bar - $5 \mu \mathrm{m}$ ).

Figs 3, 4. Stereopair of the specimen dissected by H. Tappan (scale bar - 100 $\mathrm{mm}$ ).

Figs 7-8. Close-ups of same dissected specimen; Fig.7, The toothplate (t) is clearly visible as the thin plate running from foramen to foramen (scale bar - $50 \mu \mathrm{m})$.

Fig.8. Just below the toothplate (t), the foramen (f) can be seen, showing the resorption of the apertural flap. Note also the overall organisation, including the partial compression of the individual chambers (scale bar - $20 \mu \mathrm{m}$ ). Micrographs shown in Figs 3,4,7, 8, taken using the 'Environmental Chamber' technique, without coating. 


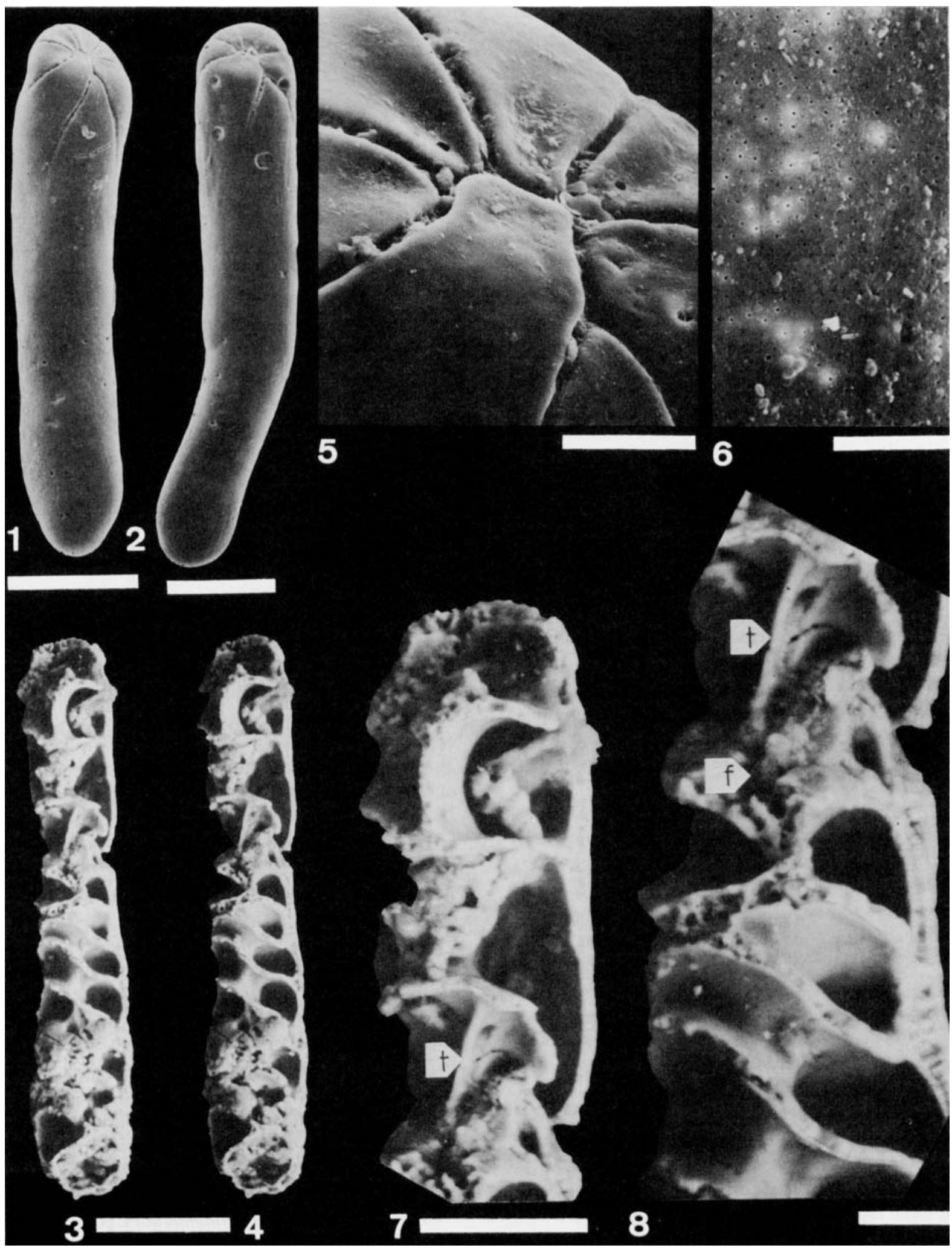




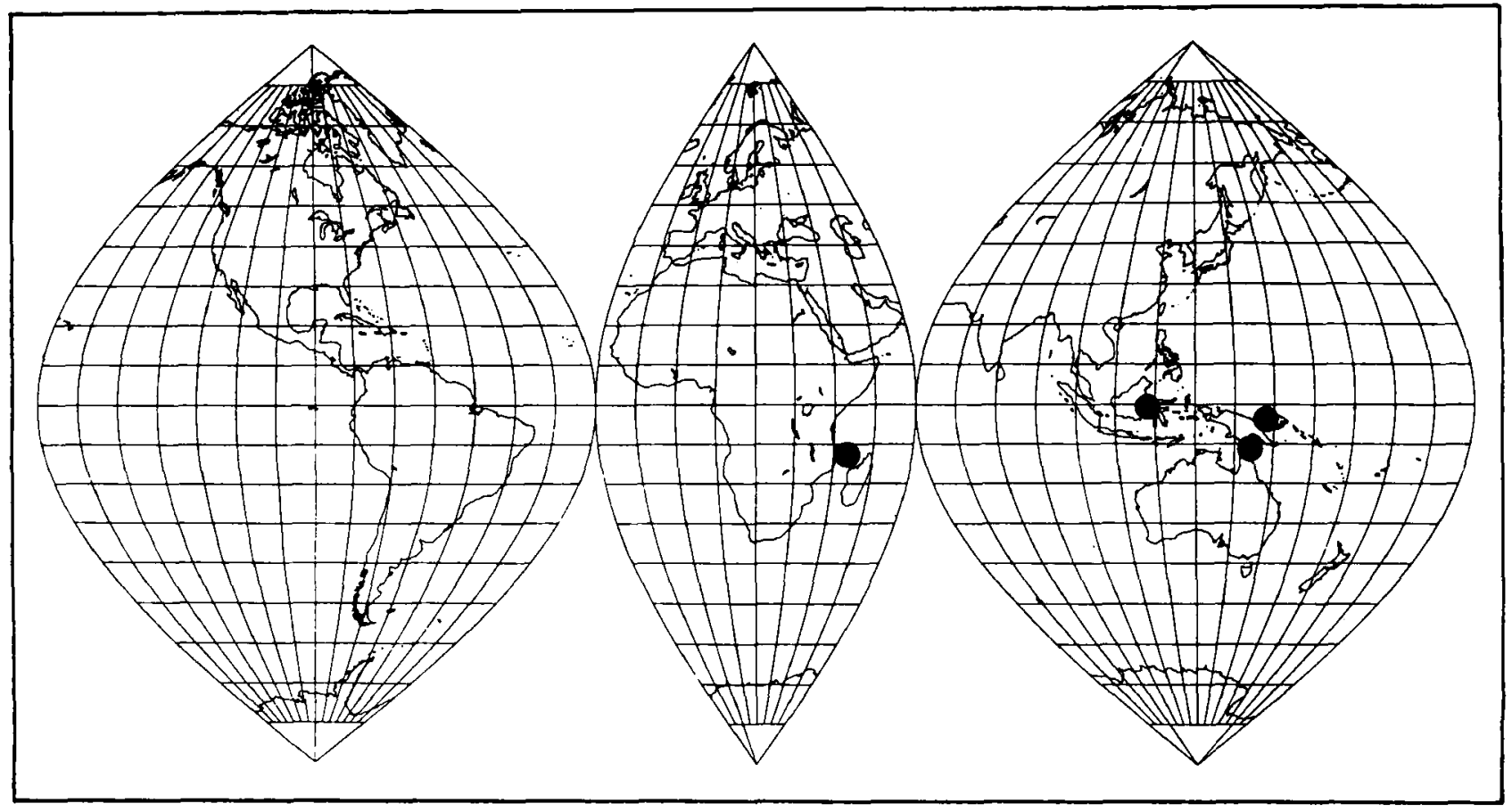

Fig. 3. The distribution of Orthoplecta. The occurrence of $O$. clavata seems to be restricted to the shelf zones in the tropical regions of the western Pacific Ocean.

\section{DISCUSSION}

When Brady described Orthoplecta clavata, he apparently had only one specimen to hand. Unfortunately, that specimen has a somewhat obscure aperture and, being arcuate, was mounted so that the apical aperture cannot be seen. The very irregular sutural pattern is rather confusing, so that it seems that Brady mistook an inclusion in one of the last chamners for the aperture.

Loeblich \& Tappan (1955) studied the holotype and a supplementary dissected specimen in London, the latter originating from the Heron-Allen \& Earland Collection (ex Millett), from 'Challenger' station 185, off Raine Island. Tappan's accurate drawings (see Text-fig.2) clearly show the peculiar coiling mode and explain the seemingly erratic suture pattern (Loeblich \& Tappan, 1955). However, the true nature of the coiling was not elucidated and apparently the specimen was not turned over so that no critical observation of the aperture was undertaken. Brady's description therefore remained standing. These drawings were later reproduced in the successive classifications of Loeblich \& Tappan $(1964 ; 1988)$.

The illustrations presented here (PI.1) of $O$. clavata show, for the first time, the true apertural features and the characteristic furrowed apertural face. The aperture is hidden by a low, broad flap, arising from the lowermost peripheral side, while the rest of the apertural face is furrowed by seven grooves which continue for some length over the test. However, grooves belonging to earlier chambers do not show on the surface of the test, probably due to its relatively thick secondary lamination.

The apertural face of Orthoplecta resembles that of Floresina Revets, 1990b, except that in the former the aperture is always hidden by an apertural flap. The toothplate is also quite similar, except that in Orthoplecta one border remains attached. The central part of the toothplate is also straight rather than curved as a trough throughout. Interestingly, the apertural flap seems to be resorbed when the aperture is converted into a foramen, an observation earlier made on Elongobula milletti (Revets, manuscript). Thus, while the obstruction of the apertural flap is removed, it is replaced by a toothplate. On the other hand, the shape of the individual chambers and the coiling mode is more reminiscent of Buliminoides, now excluded from the buliminids (Revets, 1990a), or some of the more elongate Elongobula species. However, the pores in Orthoplecta are extremely minute, contrary to species of both Elongobula and Buliminoides. The set of characteristics exhibited by Orthoplecta, taken together however, is more than sufficient to reclassify it close to Floresina and Elongobula. The subfamily Orthoplectinae is here raised to full family status in order to receive these three genera (Orthoplecta, Floresina and Elongobula) since they have more characters in common than with other genera in the Buliminacea.

The joint-occurrence of characters in Orthoplecta, considered to be diagnostic for several different genera, notably Elongobula, Floresina and Buliminoides, poses some interesting problems from the evolutionary point of view. Convergence is an attractive proposition. but the above mentioned 
genera seem to be too closely related to account for this similarity solely by convergence. On the other hand, true recombination of the genetic elements responsible for these morphological features is too strong a hypothesis since different genera are being considered. It is possible that Orthoplecta amongst others, is the result of a hitherto unsuspected evolutionary mechanism, and therefore deserves closer scrutiny. It seems likely that Orthoplecta is a fairly recent offshoot of the Elongobula-Floresina line, not only on morphological grounds, but also based on the biogeographic and stratigraphic information available. Orthoplecta is only known as a Recent taxon, and its occurrence seems to be restricted to the tropical Pacific Province (see Text-fig.3), contrary to Floresina, which is also encountered in the tropical parts of the New World.

\section{Manuscript received January 1990 \\ Revised Manuscript accepted June 1990}

\section{REFERENCES}

Brady, H.B. 1884. Report on the foraminifera dredged by H.M.S. 'Challenger', during the years 1873-1876. Rep. scient. Results Voy.Challenger, 9, 1-814, pls 1-115.

Chapman, F. 1901. On the Foraminifera collected around the Funafuti Atoll from shallow and moderately deep water.J.Linn.Soc. (Zool.), 28, 379-433.

Chapman, F. 1902. The Foraminifera. An introduction to the study of the Protozoa. Longmans, Green \& Co., London xv+354pp., 14 pls.

Chapman, F. \& Parr, W.J. 1936. A classification of the Foraminifera. Proc. R. Soc. Vict., 49, 139-151.

Cushman, J.A. 1927. An outline of a re-classification of the Foraminifera. Contr. Cushman Lab. foramin. Res., 3, 1-105, pls 121.

Cushman, J.A. 1928. Foraminifera, their classification and economic use. Spec. publs Cushman Lab. 1, 1-104, pls 1-59.

Galloway, J.J. 1933. A manual of foraminifera. Principia Press, Bloomington, Indiana, xii+483pp., 42 pls.

Haynes, J. 1981. Foraminifera. MacMillan, London, x+433pp., 15 pls, 14 key-figs.

Heron-Allen, E. \& Earland, A. 1915. The Foraminifera of the Kerimba Archipelago(Portuguese East Africa) - Part 2.Trans.zool.Soc.Lond., 20, 543-795, pls 40-53.

Loeblich, A.R. \& Tappan, H. 1955. Revision of some Recentforaminiferal genera. Smithson. misc. Collns, 128, 1-37, pls $1-4$.

Loeblich, A.R. \& Tappan, H. 1964. Protista 2. Sarcodina, chiefly 'Thecamoebians' and Foraminiferida. In, Moore, R.C. (Ed.), Treatise on Invertehrate Paleontology. Part C., 2 vols., Geological Society of America and University of Kansas Press, 900pp., 653 text-figs.

Loeblich, A.R. \& Tappan, H. 1982. Classification of the Foraminiferida. In, Broadhead, T.W. (Ed.), Foraminifera. Notes for a short course organised by M.A. Buzas and B.K. Sen Gupta. Univ. Tennessee Stud. Geol.,6, 22-36.

Loeblich, A.R. \& Tappan, H. 1984. Supregeneric classification of the Foraminiferida (Protozoa). Micropalaeontology, 30, 1-70.

Loeblich, A.R. \& Tappan, H. 1988. Foraminiferal genera and their classification. Van Nostrand Reinhold Co., New York, 2 vols., x+970pp.; viii+212pp, 847 pls.

Rauzer-Chernousova, D.M. \& Fursenko, A.V. 1959. Osnovy Paleontologii. Obshchaya chast prosteyshie. Akademiya Nauk, SSSR, 368pp., 13 pls.

Revets, S.A. 1990a. The revision of Buliminoides Cushman, 1911.J. foramin. Res., 20, 50-55

Revets, S.A. 1990b. The genus Floresina gen. nov. J. Foramin. Res., 20, 157-161. 